\title{
Effect Of Alpha-Tocopherol On Spermatozoa Death Of Apoptosis and Necrosis in Rats (Rattus Norvegicus) Exposed 2,3,7,8- Tetrachlorodibenzo-P-Dioxin
}

\author{
Valderama Gomang ${ }^{*}$, Dewa Ketut Meles$^{2}$, Soeharsono ${ }^{3}$, Arimbi ${ }^{4}$, \\ Wurlina $^{5}$, Iwan Sahrial Hamid ${ }^{6}$ \\ ${ }^{1}$ Faculty of Veterinary Medicine, Airlangga University \\ ${ }^{2}$ Department of Basic Veterinary Medicine, Faculty of Veterinary Medicine, Airlangga \\ University \\ ${ }^{3}$ Department of Veterinary Anatomy, Faculty of Veterinary Medicine, Airlangga University \\ ${ }^{4}$ Department of Veterinary Pathology, Faculty of Veterinary Medicine, Airlangga University \\ ${ }^{5}$ Department of Reproduction, Faculty of Veterinary Medicine, Airlangga University \\ ${ }^{6}$ Department of Basic Veterinary Medicine, Faculty of Veterinary Medicine, Airlangga \\ University \\ *Corresponding author: ramagomang5@gmail.com
}

\begin{abstract}
The aims of this research was to investigate effect of alpha-tocopherol on spermatozoa death in form of apoptosis and necrosis in rats (Rattus norvegicus) exposed 2,3,7,8- tetrachlorodibenzo-p-dioxin. Male rats were administered TCDD and alpha-tocopherol in experimental groups. Five experimental groups of a combination of TCDD and alpha- tocopherol were designed as follows; $0.5 \mathrm{ml}$ of corn oil (control negative group, K-), $700 \mathrm{ng} / \mathrm{kg} / \mathrm{d}$ of TCDD and $0.5 \mathrm{ml}$ of corn oil (treatment control), $700 \mathrm{ng} / \mathrm{kg} / \mathrm{d}$ of TCDD and 77 $\mathrm{ng} / \mathrm{kg} / \mathrm{d}$ of alpha-tocopherol (Group P1), $700 \mathrm{ng} / \mathrm{kg} / \mathrm{d}$ of TCDD and $140 \mathrm{mg} / \mathrm{kg} / \mathrm{d}$ of alpha-tocopherol (Group P2), $700 \mathrm{ng} / \mathrm{kg} / \mathrm{d}$ of TCDD and $259 \mathrm{mg} / \mathrm{kg} / \mathrm{d}$ of alpha- tocopherol (Group P3) respectively. Alphatocopherol and TCDD were given by oral gavage for 20 days. The result indicated that TCDD increased spermatozoa death in form of apoptosis and also necrosis. Alpha-tocopherol at $259 \mathrm{mg} / \mathrm{kg} / \mathrm{d}$ most effective to decreased spermatozoa death number. The conclusion indicated that alpha-tocopherol at $259 \mathrm{mg} / \mathrm{kg} / \mathrm{d}$ effective to decreased the spermatozoa death in form of apoptosis and necrosis in rats (Rattus norvegicus) exposed 2,3,7,8-tetrachlorodibenzo-p-dioxin.
\end{abstract}

Keywords: Alpha-tocopherol, Spermatozoa, Apoptosis, Necrosis, 2,3,7,8-tetrachlorodibenzop-dioxin (TCDD)

\section{INTRODUCTION}

Environmental pollution is an event that spreads certain levels of chemicals that can disrupt the balance of the environment. Chemicals are spread freely in the environment and can directly contaminate humans, animals, and even plants. one of the chemicals that can cause environmental pollution is dioxin. (Matsusshita, 2003; NIEHS, 2001). In an epidemiological study conducted by Guo et al., (2004) found a case of exposure to dioxin compounds in workers in Flemish who lived close to a factory incinerator waste disposal 
center. Conditions due to exposure that occurred showed an increase in spermatozoa morphological abnormalities, decreased motility, and decreased oocyte penetration ability in men exposed to dioxin during the perinatal and lactation periods, as well as in men exposed in adulthood.

Dioxin is a toxic compound that belongs to the group of environmental contaminants which are mainly produced through industrial processes such as burning plastic waste, power plants, and making herbicides and pesticides (Procopec et al., 2013; Ribeiro et al., 2019). The most toxic compounds in the group categorized in the dioxin group are 2, 3, 7, 8-Tetrachlorodibenzo-p-dioxin (TCDD). TCDD compounds are non-polar lipophilic compounds whose solubility will decrease in water and increase in organic solvents or fats such as hexane, because they are accompanied by chlorine content (Geyer et al., 2002; McKay., 2002). Exposure to dioxin can accumulate in human foodstuffs such as milk and dairy products, meat fat tissue, chicken eggs, and the process of burning waste, especially those made from plastic (Ciftci et al., 2010).

According to research (Ciftci et al., 2011) 2,3,7,8-Tetrachlorodibenzo-p-dioxin has been shown to cause various responses in the body including as a trigger for cancer (carcinogenic), reproductive disorders, wasting syndrome, hepatotoxic, nephrotoxic and failure. immune function. Dioxin exposure has a negative impact on reproductive organs through decreased activity of the hypothalamus in the synthesis of
GnRH which plays a role in the formation of FSH and ICSH by the pituitary gland (Latchoumycandane et al., 2003). As a result of the decrease in FSH hormone secretion, it causes a decrease in the number of Sertoli cells which function to nourish spermatogenic cells during the period of spermatogenesis. While the decrease in ICSH results in a decrease in the hormone testosterone produced by Leydig cells in the interstitial tubules of the testes (Yen et al., 2012).

The decrease in the work activity of reproductive hormones will disrupt the process of spermatogenesis which is one of the consequences of the mechanism of death of spermatozoa. Changes that can occur in the form of a decrease in the diameter of tubular cells and spermatogenic cells, abnormalities in the shape of the tail and head of spermatozoa, and even death of spermatozoa through apoptosis and necrosis mechanisms (Bujan et al., 2013).

Vitamin $\mathrm{E}$ is one of the fat-soluble vitamins and non-enzymatic antioxidants. Vitamin E can prevent and reduce cell damage caused by oxidative stress after dioxin administration by preventing lipid peroxidation by Reactive Oxygen Species on cell membranes. Vitamin E has also been shown to improve the quality of spermatozoa through in vivo studies by neutralizing the effects of free radicals. Vitamin $\mathrm{E}$ is divided into several species and the one that has the best antioxidant ability is the alpha-tocopherol group (Uzunhisaarcikli and Calendar., 2011) 


\section{METHODS}

25 male white rats (Rattus norvegicus) Wistar strain aged 10-12 weeks were divided into five treatment groups, each group consisted of five mice. Control negative (K-) ie the group of rats that were only given $0.5 \mathrm{ml}$ of corn oil/day, the control treatment $(\mathrm{P} 0)$ was the group of rats that were given TCDD $700 \mathrm{ng} / \mathrm{kgBW} /$ day and 0.5 $\mathrm{ml}$ of corn oil/day, treatment 1 ( P1) is a group of rats given TCDD $700 \mathrm{ng} / \mathrm{kgBW} /$ day and alphatocopherol $77 \mathrm{mg} / \mathrm{kgBW} /$ day, treatment $2(\mathrm{P} 2)$ is a group of rats given TCDD $700 \mathrm{ng} / \mathrm{kgBW} /$ day and alpha-tocopherol $140 \mathrm{mg} / \mathrm{kgBW} /$ day, and treatment 3 (P3), namely a group of rats that were given TCDD $700 \mathrm{ng} / \mathrm{kgBW} /$ day and alphatocopherol $259 \mathrm{mg} / \mathrm{kgBW} /$ day.

Rats were kept in experimental animal laboratory cages, with feeding once a day. Giving TCDD treatment to groups $\mathrm{P} 0, \mathrm{P} 1, \mathrm{P} 2$, and $\mathrm{P} 3$ and giving corn oil to group $\mathrm{K}$ - started at 09.00 . Then after four hours, alpha-tocopherol was given to groups P1, P2 and P3 and corn oil was given to groups P0. The treatment was given for 20 days.

Surgery was performed on day 21 with the aim of taking semen through the cauda epididymis incision. The cauda epididymis is cut with a scalpel or pierced with a needle in several places, placed on the collection medium and then pressed until the spermatozoa come out and move away from the epididymal tissue to be collected with a pipette (Harshan et al., 2005).

Observations on the mechanism of death of spermatozoa by apoptosis and necrosis were carried out using acridin orange dye solution with a concentration of $0.2 \mathrm{mg} / \mathrm{ml}$ and ethidium bromide dye solution with a concentration of 0.2 $\mathrm{mg} / \mathrm{ml}$ in PBS solution. The solution is poured equally into the vial. Samples collected from the cauda epididymis were then taken using a pipette.

Each sample for each treatment was placed on an object glass and then the slides were stained with a mixture of acridine orange and ethidium bromide. Spermatozoa with normal DNA emit green fluorescence, while spermatozoa with apoptosis appear yellow with fragmented and necrotic cell nuclei that will appear reddishbrown in color but the nucleus undergoes pyknosis, karyorhexis, and karyolysis (Meles et al., 2015).

\section{Data analysis using SPSS (Statistical} Product and Service Solution). The test used was the ANOVA (Analysis of Variance) test followed by Duncan's test to find out the difference between the treatment groups with a significant level of 0.05 . 


\section{RESULT AND DISCUSSION}

In the ANOVA statistical test (Analysis of

Variance) there was a significant difference (p
$<0.05)$, the test was continued with Duncan's test and the following data were obtained

Table 1. Mean and Standard Deviation Percentage of Live and Dead Spermatozoa Rats (Rattus norvegicus) after 20 days of treatment.

\begin{tabular}{ccc}
\hline Group (Treatmen) & $\begin{array}{c}\text { Percentage of Live } \\
\text { Spermatozoa }\end{array}$ & $\begin{array}{c}\text { Percentage of Dead } \\
\text { Spermatozoa }\end{array}$ \\
\hline K- & $70,80^{\mathrm{d}} \pm 13,33$ & $29,20^{\mathrm{a}} \pm 13,30$ \\
P0 & $06,80^{\mathrm{a}} \pm 06,83$ & $93,20^{\mathrm{d}} \pm 06,83$ \\
P1 & $35,20^{\mathrm{b}} \pm 05,97$ & $64,80^{\mathrm{c}} \pm 05,97$ \\
\hline
\end{tabular}

Note: Different superscripts $\left({ }^{\mathrm{a} b}\right)$ in the same column show significant differences $(\mathrm{p}<0.05)$.

Table 2. Mean and Standard Deviation Percentage of Rat Spermatozoa (Rattus norvegicus) after 20 days of

\begin{tabular}{cccc}
\hline $\begin{array}{c}\text { Group } \\
\text { (Treatment) }\end{array}$ & $\begin{array}{c}\text { Apoptosis } \\
\text { Spermatozoa }\end{array}$ & Nekrosis Spermatozoa & Live Spermatozoa \\
\hline K- & $19,80^{\mathrm{a}} \pm 11,03$ & $09,40^{\mathrm{a}} \pm 03,20$ & $70,80^{\mathrm{a}} \pm 13,33$ \\
P0 & $79,60^{\mathrm{c}} \pm 14,15$ & $13,40^{\mathrm{ab}} \pm 09,01$ & $06,80^{\mathrm{d}} \pm 06,83$ \\
P1 & $39,00^{\mathrm{b}} \pm 10,02$ & $26,00^{\mathrm{c}} \pm 07,96$ & $35,20^{\mathrm{b}} \pm 05,97$ \\
\hline
\end{tabular}

Note: Different superscripts $\left({ }^{\mathrm{a} b}\right)$ in the same column show significant differences $(\mathrm{p}<0.05)$.

The results of statistical data analysis using one way ANOVA and continued with Duncan's test, in table 1 shows that the percentage of live spermatozoa and the percentage of dead spermatozoa in group $\mathrm{K}$ - had a significant difference between P0 and P1 ( $\mathrm{p}<0.05)$.

Table 2 shows the percentage of spermatozoa apoptosis and the percentage of live spermatozoa showed that the K-group had a significant difference with P0 and P1 ( $<<0.05)$. The percentage of spermatozoa necrosis showed that $\mathrm{K}$ - had a significant difference $(\mathrm{p}<0.05)$ with the P1 group but not significantly different from the $\mathrm{P} 0$ group $(\mathrm{p}>0.05)$.

In table 1 , it can be observed that the highest spermatozoa mortality occurred in the P0 group who were given a dose of TCDD 700 $\mathrm{ng} / \mathrm{kgBW} /$ day without alpha-tocopherol treatment. Based on these results, it can be seen that the administration of TCDD can increase the mortality rate of spermatozoa through various factors, one of which is an increase in free radical activity (Bujan et al., 2013).

Free radicals are formed due to the binding between AhR and ARNT receptors after TCDD exposure. The next AhR-ARNT binding will bind to specific DNA sequences called Xenobiotic Responsive Elements and change the expression of the Cytochrome P450 1A1 gene (Warlina, 2009, Wurlina, et al. 2020). The initial mechanism that often occurs due to free radical reactions is lipid peroxidase. Lipid peroxidase 
often occurs in cell membranes, especially from unsaturated fats which are a common component of cell membranes. The product produced by the oxidation of unsaturated fatty acids is malondialdehyde which is toxic to cells (Agarwal et al., 2004, Wurlina, et al. 2020).

Spermatozoa death due to TCDD exposure occurs through apoptotic and necrotic mechanisms. Apoptosis or programmed cell death is a normal cell death process that occurs in every cell in the process of proliferation and differentiation such as red blood cells, epithelial cells, liver cells, and other body cells. Apoptosis is needed so that the number of cells remains stable from the mitotic process in a state of balance (Wurlina, et al. 2020).

Necrosis is a condition of cell death that does not follow the apoptotic signal transduction pathway, but various receptors are activated and result in loss of cell membrane integrity and uncontrolled release of products of cell death into the extracellular space (Meles et al. 2004, Adnyana et al. 2012)

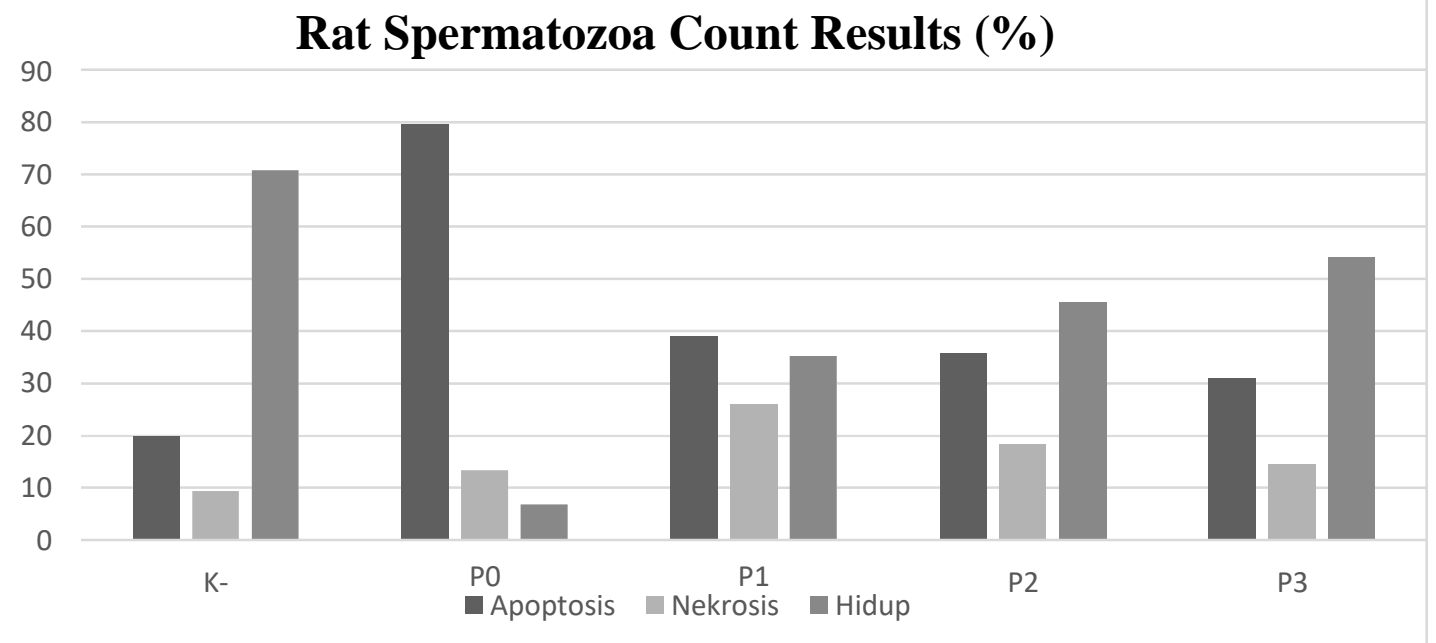

Figure 1. Graph of the percentage of rat spermatozoa count results (Rattus norvegicus) after treated with TCDD Alpha-Tocopherol for 20 days.

Based on the graph in Figure 1, it can be observed that there was a decrease in the mortality rate of spermatozoa in groups P1, P2 and P3 given alpha-tocopherol. This shows that the antioxidant content is able to reduce the state of apoptosis in rat spermatozoa (Rattus norvegicus) caused by the accumulation of TCDD compounds in the body. So that the treatment control group (P0) still showed a high spermatozoa mortality rate, this was caused by exposure to TCDD which interfered with hormonal secretions such as the testosterone hormone produced by Leydig cells, thus causing a disruption in the process of spermatogenesis (Wurlina, et al. 2020) .

The percentage of live spermatozoa in the P3 group showed no significant difference ( $p>0.05)$ with the K-group. This shows that there is an effect of the dose of alpha-tocopherol given that is effectively able to reduce the rate of 
apoptosis in spermatogenic cells, especially spermatozoa, to close to normal conditions. In this case, the administration of a dose of alphatocopherol in the treatment group at a dose of 259 $\mathrm{mg} / \mathrm{kgBW} /$ day was effective in reducing the mechanism of apoptotic spermatozoa death due to exposure to TCDD. This is because alphatocopherol acts as an electron donor in free radical bonds and stabilizes it so that it becomes unreactive (Wurlina, et al. 2021).

Alpha tocopherol contained in cell fat, functions to protect unsaturated phospholipids in cell membranes from oxidative degradation of high reactive oxygen species due to TCDD toxicity.

\section{CONCLUSION}

The conclusion in this study was that the administration of alpha-tocopherol was able to effectively reduce the rate of cell death in the form of apoptosis and necrosis of spermatozoa in

\section{REFERENCES}

Adnyana, D.P.A, D.K. Meles and Wurlina. 2012. Alkaloid Fraction of Jarong (Achyranthes Aspera Linn) Leaf InducedApoptosis Breast Cancer Cell Through p53 Pathways. Advances in Natural and Applied Sciences. Vol. 6(2); 124-127. Jan-March. 2012.

Agarwal, A., I. Ikemoto and K.R. Loughlin, 2004. Levels of reactive oxygen species before and after sperm preparation: comparison of swim up and L4 filtration methods. Arch Androl 32: 169 - 174.

Bujan, L., Walchaerts, M.,Moinard, N.,Hennebicq, S.,Saias, J.,Brugnon,
Alpha tocopherols have an antagonistic effect on TCDD induction via mechanisms such as suppression of aryl hydrocarbon receptor (AhR) that mediates gene expression induced by TCDD. Alpha tocopherol inhibits the transcription and expression of cytochrome-450 and steroid genes dehydrogenase through inhibition of TCDD induction of AhR activity. Alpha tocopherol has the effect of decreasing the activity of oxidative stress and reducing hydrogen dioxide caused by TCDD compounds. Through these various mechanisms, alpha-tocopherol can improve the condition of spermatozoa exposed to TCDD (Wurlina, et al. 2020, Wurlina, et al. 2021).

rats (Rattus norvegicus) exposed to the compound 2,3,7,8-tetrachlorodibenzo-p-dioxin (TCDD).

F.,Auger, J.,Berthaut, I.,Szerman, E.,Daudin, M.,Rives, N. 2013.Impact of chemotherapy and radiotherapu for testicular germ cell tumors on spermatogenesisand sperm DNA; A multicenter prospectivestudy from the CECOS network. Fertil. Steril. 100, 673-680.

Latchoumycandane, C., K. C. Chitra, and P.P. Mathur. 2003. 2,3,78 Tetrachlorodibenzo-p-dioxin (TCDD) induces oxidative stress in the epididymal sperm of adult rats. Arch Toxicol. 77: 280-284 
Matsushita, M. (2003). Enabling Facilities to Facilitate Early Action on Implementation of the Stochkolm Convention on Organics Pollutants (POPs) in Indonesia, makalah pada Workshop Sosialisasi Hasil Inventarisasi Bahan Kimia POPs di Indonesia. Jakarta: KLH.

Meles D.K., Adnyana I.D.P.A., Zakaria S, Putra D.M.S., Suasanti N. 2015. The Antimitogenic Effect of Alkaloid Fraction of Achyranthes aspera Linn on Apoptotic Induction in Mice Infected by Mycobacterium tuberculosis. Acta Veterinaria Indonesiana. Vol.3, No. 1; 8-15.

Meles D.K; W. Sastrowardoyo; Wurlina.2004. Efek Antifertilitas Ekstrak Impatiens balsamina Linn Terhadap Integritas MembranSpermatozoa Secara In Vitro. Medika Eksakta. 5(1); 43-52. ISSN 1411-6626.

Wurlina; D. K. Meles; I. Mustofa; E. Safitri; S. Zakaria; A. Basori; D. K. S. C. Putri; N. Suwasanti. 2018. Effect of Alkaloid of Achyranthes aspera Linn (Caryophyllales amaranthaceae) on Increasing Caspase 9, Caspase 3 and Apoptosis in Micewith Breast Cancer. The Philippine Journal of Veterinary
Medicine. 1(5): 51-58. Special Issue. December 2018. ISSN. 0031-7705.

Wurlina; I. Mustofa; Sri Mulyati; D. K. Meles. 2020. Administration of $\alpha$ Tocopherol to Spermatogenic Staging and Leydig Cell on Rats Exposed 2,3,7,8tetrachlorodibenzo-p-dioxin. Faculty of Veterinary Medicine Universitas Brawijaya. Abstract Book. E-ISSN: 2721-6691.

Wurlina; E. Safitri; I. Mustofa; N. L. Rahmania; D. K. Meles; S. Mulyati; N. Suwasanti. 2021. Antioxidant $\alpha$ Tocopherol Against Leydig Cell Number, Testosterone and MDA Levels and SOD Activity in Rats Exposed to 2,3,7,8tetrachlorodibenzo-p-dioxin (TCDD). International Journal of Pharmaceutical Research. Faculty of Veterinary Medicine Airlangga University. Vol 13 Issue 2. ISSN: 0975-2366.

Yin, H.P., J.P. Xu, X.Q. Zou, and Y. Wang. 2012. Effects of vitamin E on reproductive hormones and testis structure in chronic dioxin- treated mice. Toxicology and Industrial Health. 152161 